\title{
World Congress of Gastroenterology 2005 Canadian Bid Federation
}

Dear CAG Member:

After serious and extensive deliberation, the Canadian Association of Gastroenterology (CAG) Board of Directors approved a process that would permit Canada to place a bid to host the 13th World Congress of Gastroenterology Meeting, September 2005.

In the spring of this year, a World Congress of Gastroenterology 2005 Canadian Bid Federation Executive Council was struck to coordinate Canada's bid. Over a period of three months, and with an enormous amount of support from Chateau Travel, a bid document was assembled (52 pages) to meet the Organisation Mondiale de Gastro-Entérologie (OMGE) bid deadline of July 1, 2000.

Below is the CAG's letter to the OMGE, which accompanied the bid.

June 5, 2000

Professor Meinhard Classen

President, World Organization of Gastroenterology

Dear Dr. Classen:

On behalf of the Canadian Association of

Gastroenterology I am honored to present Canada's bid for the 13th World Congress of Gastroenterology to be held September 15th - 24th, 2005, Montreal, Quebec, Canada.

Canada has established a distinguished and international presence in gastroenterology, and plays a salient leadership role in gastrointestinal and hepatobiliary research, education and clinical care.

The Canadian Association of Gastroenterology and Chateau Travel PCO orchestrate the highly successful annual Canadian Digestive Disease Week which attracts international delegates and over $80 \%$ of Canadian gastroenterologists. In 1999 Canada staged the largest, and the most successful, Pan American Congress of Gastroenterology meeting ever held, hosting over 3000 world delegates. Leadership ensured that this meeting provided SIED and AIGE with endowments from which to launch research and educational initiatives.

There is no doubt that the Canadian Association of Gastroenterology and its members will organize and stage a World Congress of Gastroenterology 2005 that will not only meet the directed goals of the OMGE, but will establish a standard of excellence for World Congress meetings into the future.

Canada itself is an ideal country to host the World Congress of Gastroenterology. It is consistently recognized by the international citizenry as 'the greatest country in the world to live in'. Montreal is a fabulous city; safe, clean, cosmopolitan, vibrant and affordable it has flawlessly hosted numerous world congress scientific meetings and exhibitions.

The Board of Directors of the Canadian Association of Gastroenterology and its membership have unanimously endorsed this bid. Furthermore, the Local Host Committee will work to abide by the rules, policies and regulations as outlined in the bid manual.

Working along side OMGE, OMED, ICSG, and with Chateau Travel PCO's assistance, we will execute a meeting which fulfills the needs of all member societies, exchanging state of the art clinical and scientific knowledge and educating gastroenterologists, gastrointestinal scientists and health professionals worldwide. 
On behalf of the Canadian Association of Gastroenterology, we want to thank you for considering our bid and hope you find this application of significant value to the OMGE. We look forward to your site visit and the opportunity to showcase the outstanding facilities that will host the World Congress of Gastroenterology in 2005.

Sincerely,

RICHARD N FEDORAK, MD, FRCPC

Past President, Canadian Association of

Gastroenterology

President, World Congress of Gastroenterology 2005

Canadian Bid Federation

\section{WHAT IS THE PRESENT STATUS OF CANADA'S BID?}

It has been confirmed that the OMGE has accepted two bids to host the 2005 World Congress Meeting: Canada's bid and Argentina's bid. Because there are now two countries in the competition, a 'run-off' selection process will be held in Bangkok at the time of the 2002 World Congress Meeting. Presidents of each of the 85 world gastroenterology societies will be asked to select between Canada and Argentina.

\section{WHERE IN CANADA WILL THE 2005 WORLD CONGRESS BE HELD?}

The CAG Bid Federation went through a thorough site selection process. Because the World Congress Meeting will be attended by over 15,000 delegates, there are only two cities in Canada with sufficient hotel and convention space to host such a meeting. Both Toronto and Montreal were thus visited and reviewed. In the final analysis, a detailed 'plus/minus' assessment favoured Montreal, both financially and because of a superior selection of dates.

\section{WHAT IS THE ADMINISTRATIVE STRUCTURE FOR THE BID?}

The World Congress of Gastroenterology 2005 Canadian Bid Federation has developed a set of bylaws and formed a legal society under the Canada Societies Act. Under this structure, the CAG can guide the bid process and World Congress 2005 Meeting without direct liability.

Within the Federation, the following Executive Council and Governing Board was established to direct the bid process:

Chair, Scientific Program Committee: Dr John Wallace

\author{
Chair, Young Clinicians Program Committee: \\ Dr Alan Barkun \\ Chair, Press and Congress News Committee: \\ Dr Hugh Chaun \\ Chair, Social Program Committee: \\ Dr Robert Bailey \\ Chair, Advisory Committee: \\ Dr Grant Gall \\ Officer, Vice Chair: \\ Dr Michel Boivin \\ Officer, Vice Chair: \\ Dr Gary Levy \\ Officer, Vice Chair: \\ Dr Mary Perdue \\ Officer, Vice Chair: \\ Dr Lloyd Sutherland \\ Officer, Vice Chair: \\ Dr Sander van Zanten
}

Supporting the Executive Council will be a national advisory committee. The Federation seeks a broad spectrum of representation on the national advisory committee and has thus written to each of the provincial gastroenterology societies requesting a slate of nominees. The national advisory committee will assist in the bid process up to the selection in 2002, and once the bid is secure will have a considerable role to play in the development of the meeting agenda, program and design.

\section{WHAT IS THE PROCESS TO PREPARE FOR THE SELECTION VOTE IN 2002?}

In preparation for Canada securing a positive outcome to the selection process in Bangkok (a vote between Canada and Argentina), the CAG and Chateau Travel have committed resources to two specific elements - constructing and manning a promotional booth, and hosting an informational session for the 85 societal presidents and secretaries (the voting members) at each of the following major international meetings:

United European Gastroenterology Week November 25 to 30, 2000, Brussels, Belgium

Digestive Disease Week May 19 to 23, 2001, Atlanta, Georgia

United European Gastroenterology Week October 6 to 10, 2001, Amsterdam, the Netherlands

Pan American Meeting of Gastroenterology October 29 to November 3, 2001, Lima, Peru

No CAG or Federation members are being sponsored to attend these meetings as part of this bid process. However, the Federation is aware that a number of CAG members will be at these meetings for separate reasons, and will subsequently be asking these individuals to serve as ambassadors of the CAG booth and information session. 


\section{WHAT IS THE BUDGET FOR THIS BID PROCESS?}

The CAG Board of Directors has agreed to fund this bid process up to an amount of $\$ 80,000$. In addition, the City of Montreal has committed significant resources to ensure that the OMGE site visit to Montreal is a success and to ensure that an adequate contingent can be present in Bangkok to secure a positive vote. Finally, Chateau Travel and the Federation Executive Council are working hard to secure resources from the Province of Quebec, the City of Montreal and Air Canada to further offset any costs that may be incurred. The plan is to secure this bid for Canada at a minimal cost to the CAG.

\section{WHY SHOULD THE CAG BID FOR THE WORLD CONGRESS MEETING?}

I believe that Dr John Wallace summed it up best in a previous newsletter (1):

There are three main reasons. First, there would be a significant financial dividend for the host country. The WCOG will attract on the order of 15,000 delegates, with their overall spending estimated to be close to $\$ 40$ million. Of course, if the delegates are suitably impressed by what Canada has to offer, there would be additional financial benefits in the way of future tourist dollars.
Second, there would be a significant financial dividend for the CAG. The recent Gastro '99 meeting in Vancouver, British Columbia, having reached its target registration of 3000 , yielded a return to the CAG of over $\$ 400,000$, which can be used to support the research and education activities of the Association. Finally, successfully hosting the WCOG would provide a 'reputation' dividend to Canadian gastroenterology.

This is an important venture for Canada, for the CAG and for gastroenterologists in this country. Please consider volunteering to help make this one of the best World Congress Meetings ever held.

\section{REFERENCE}

1. Wallace J. The CAG News Page. Can J Gastroenterol 2000;14:475-6.

Richard N Fedorak MD

Past President, Canadian Association of Gastroenterology President, World Congress of Gastroenterology 2005 Canadian Bid Federation

Philip Sherman MD President Elect, Canadian Association of Gastroenterology Vice-President, World Congress of Gastroenterology 2005 Canada Bid Federation 


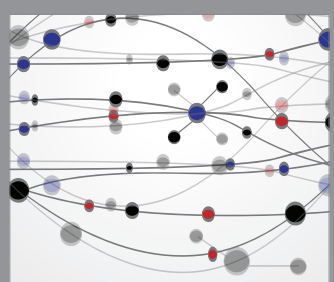

The Scientific World Journal
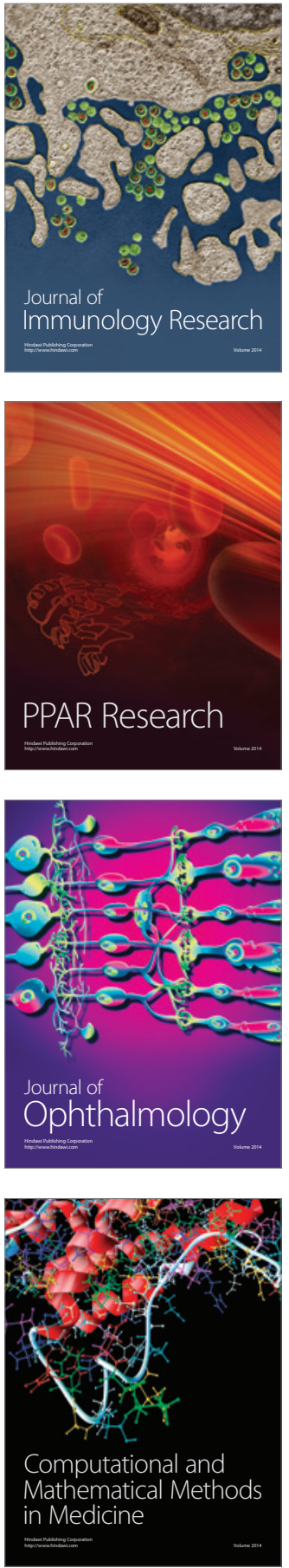

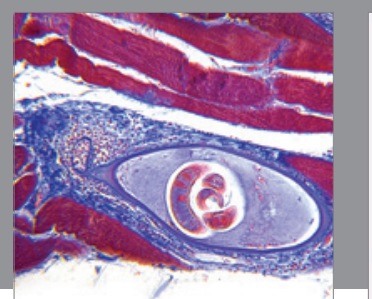

Gastroenterology Research and Practice

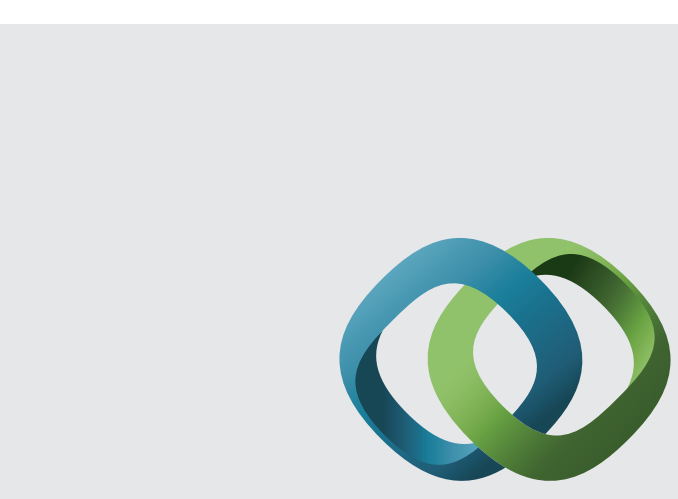

\section{Hindawi}

Submit your manuscripts at

http://www.hindawi.com
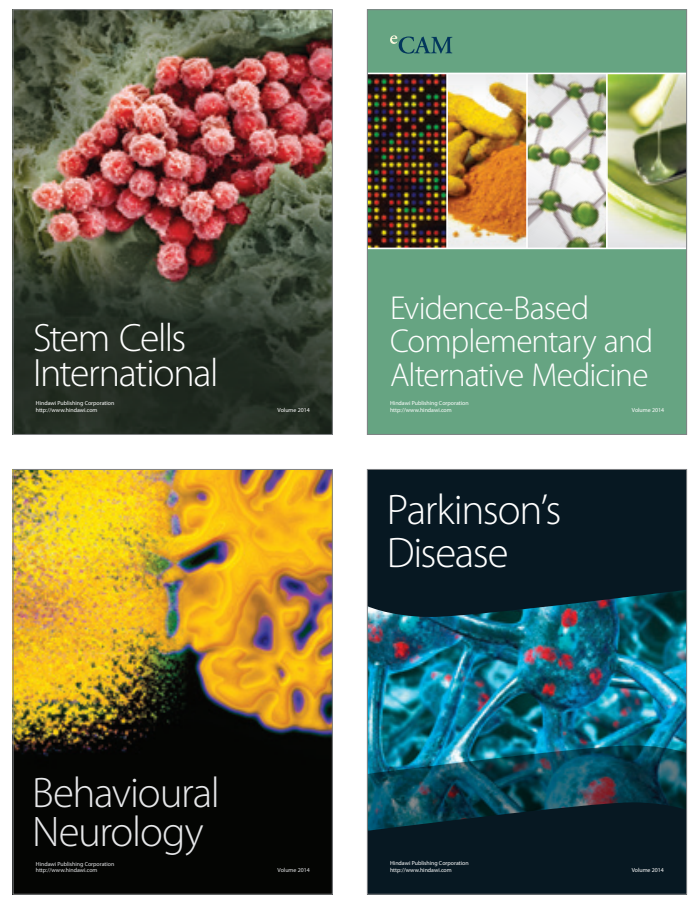
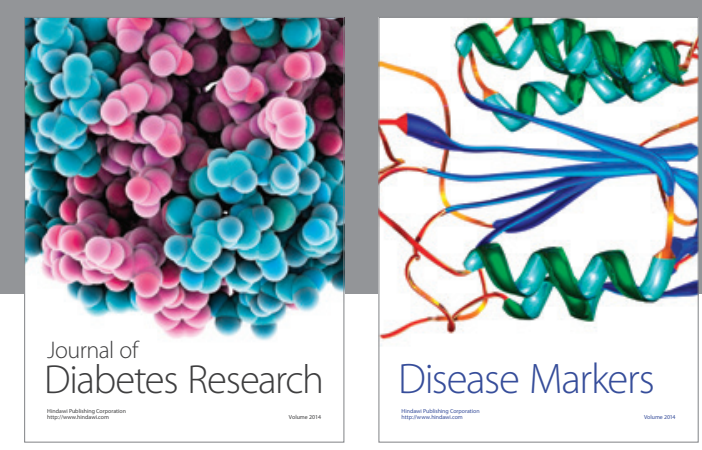

Disease Markers
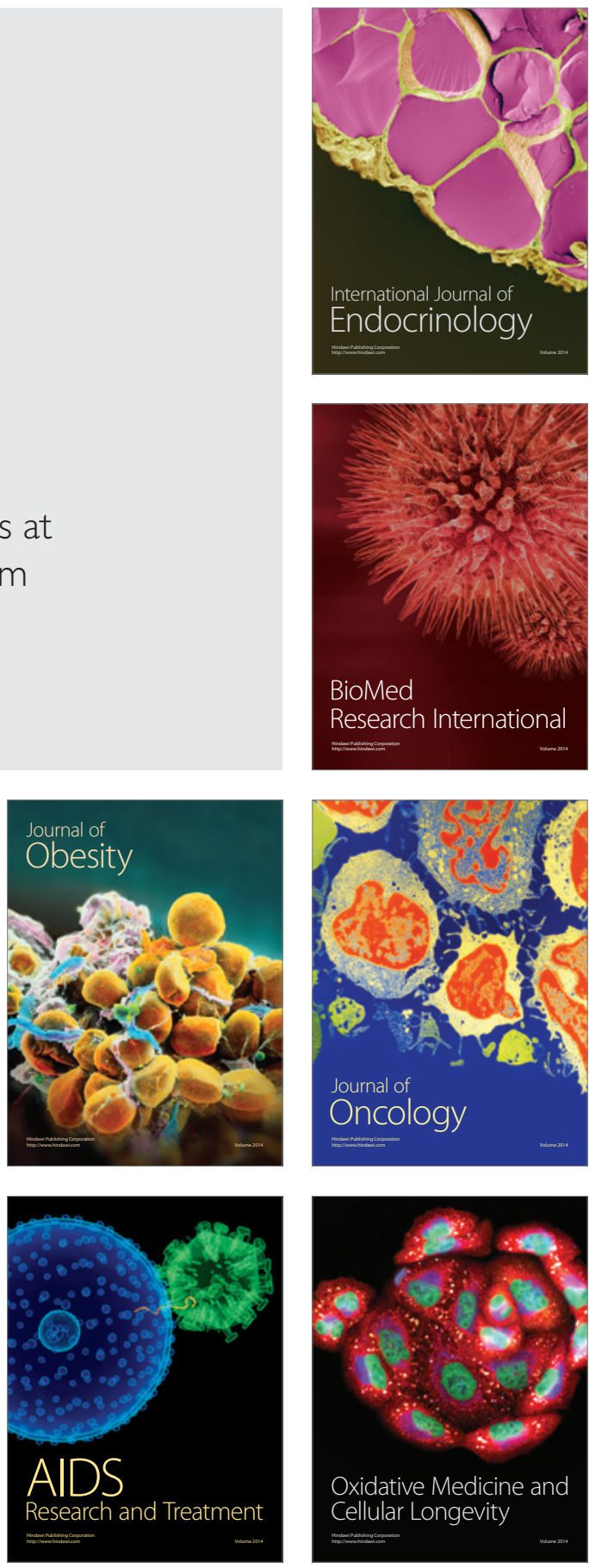